\title{
Evaluation of Various Local Rice Genotypes in the Mandailing Natal Province of North Sumatra
}

\author{
Erti Kumla Indah Nasution ${ }^{1}$, Benni Satria ${ }^{2}$, Gustian ${ }^{3}$ \\ ${ }^{1}$ Department of Agriculture, Andalas University, Indonesia \\ Email: erti.kumalaindah@gmail.com \\ ${ }^{2}$ Department of Agriculture, Andalas University, Indonesia \\ Email: bennisatria1965@gmail.com/ benni bd@yahoo.com \\ ${ }^{3}$ Department of Agriculture, Andalas University, Indonesia \\ Email: gustian burhan@yahoo.com
}

\begin{abstract}
The purpose of this study was to evaluation of several local rice genotypes in the Mandailing Natal Province of North Sumatra. This studay was and has been conducted from April 2017 to October 2017. Data observed in the form of quantitative data and qualitative data of local rice plants. The results showed that rice cultivars were found in various regions in Mandailing Natal District with a high variety of characteristics. Sampling was done by purposive sampling from 23 subdistricts in Mandailing Natal District. Data observed in the form of quantitative data and qualitative data of local rice plants. The results showed that rice cultivars were found in various regions in Mandailing Natal District with a high variety of characteristics. The sigudang genotype was the best genotype with a total grain weight of 82.6 grams. Genotype Sisorang have a good agronomic appearance.
\end{abstract}

Keywords- Local rice plants, Germplasm, Characterization, exploration.

\section{INTRODUCTION}

Rice (Oryza sativa L.) is one of the most important food crops. Rice is a staple food source for almost all Indonesian people. therefore rice becomes a commodity that can have a serious impact on the social, economic and political fields.

Through the initiation of plants, genetic resources are a source of hereditary traits that are useful for assembling a new superior variety with certain traits[4] and [12]. The genetic resources of rice are very important for Indonesia because they are a source of hereditary characteristics for superior rice assembly which is a very strategic commodity in Indonesia [6] and [7]. Local rice is one source of genetic diversity that has unique characteristics such as resistance to disease and aroma and kepulenan which is very favored by the people of Indonesia in general. Even based on the results of Brar and Krush's study, where if the local rice is classified as wild rice, it is likely that it has potential properties that are useful for breeding such as the nature of resistance, especially for biotic and abiotic stresses. To maintain the genetic resources of local rice, it is necessary to carry out an inventory of local rice in a location. One area that still has a large variety of local rice cultivars is Mandailing Natal District. The rice cultivars have been cultivated by local farmers for generations.

With the availability of superior varieties with desirable traits is the goal of improving rice varieties. This will not materialize without the genetic diversity of rice germplasm. In some cases, cultivated rice germplasm diversity for important traits such as pest resistance, drought tolerance and salinity is very limited. Given the importance of rice to human life, the existence of local rice genetic resources (SDG) needs to be preserved. In the condition of paddy fields, the use of superior varieties of lowland rice cannot solve the problems faced [5], [7], [9] and[12].

However, local rice varieties for an area do not necessarily show the same superiority in other regions, because in Indonesia it is very religious, including the highlands. This is caused by the influence of the interaction between the genotype and the growing environment.

The program of starting rice plants in producing new high-yielding varieties with high yield productivity and stability requires gene sources from plant characteristics that support this goal. The sources of genes from these traits need to be identified and found in germplasm through germplasm characterization activities that already exist and must be conserved so that they are always available both now and in the future and are beneficial for 
plant breeding. The genes that appear to be now not useful, in the future may be needed in the formation of new superior varieties.

This present study was aimed at evaluation of several local rice genotypes in the Mandailing Natal Province of North Sumatra.

\section{MATERIALS AND METHODS}

This research was carried out at the screen house of South Tapanuli Muhammadiyah University of North Sumatra Province. In April 2017 to October 2017 South Tapanuli Regency.

This study used a survey method with purposive sampling. Data collection and determination of location used as a place for sampling through a preliminary survey. Exploration method by collecting each rice cultivar planted by local residents. Plants that will be used as samples are preferred for crops that have been harvested or in the form of grain that are still stored in farm houses. There are 8 sub-districts that will be used as place for sampling plants. Each plant genotype that is used as a sample is repeated 5 times so that there are 40 units of the experiment. Then the qualitative and quantitative characters of each genotype were observed.

\section{Height of rice plants}

\section{RESULT AND DISCUSSION}

The highest plant height found in the Siganteng genotype had the highest value of $177 \mathrm{~cm}$ while the lowest plant height was found in the $87 \mathrm{~cm}$ Genotype Sis (Table 1). The shorter the rice plant, the more number of tillers produced so that it will produce maximum production. The higher the plants, the easier the plants will experience shedding and cause the distribution of metabolic processes throughout the plant to break. The flag leaf above will mostly shade the rice seedlings below it, so the higher the plant will be the greater the shade because rice plants need full light intensity in increasing their production. The diversity of rice plants is thought to be due to the more dominant differences in cultivar genetically. This is in accordance with the opinion of [9], [10] and [12] that plant height is a genetic factor of the plant itself and plant variation is its environmental factor.

\section{Flowering age of rice plants}

Based on observations of the age of flowering of rice plants in each genotype observed, the age at which the flower appeared the fastest appeared in the Genotype genotype. The age of the flower appeared, it took 95 days after planting. While the average appearance of the longest flowering age is Siganteng 150 days after planting (Table 1).

Factors that affect the speed or failure of interest are external factors which consist of temperature, solar radiation, humidity during the generative phase and internal factors such as genetics. The faster the flower's age appears, it will affect the age of the harvest [11] .

\section{Harvest age}

The fastest fastest harvesting age is found in the Sisot genotype which is 125 HST and the longest is found in the Siganteng genotype 180 HST (Table 1). This is in line with the age of interest appearing in each genotype. Where, the age of the fastest flower appears also found in the Sisoreang genotype while the age at which flowers appear at the latest is found in the Siganteng genotype. In rice plants the age of plants is an observation variable that is done to determine the right harvest time. The sooner the age of the rice plants, the farmers will feel happy by planting in a short time and high productivity. The age of the rice plants has to do with the age of harvest, $50 \%$ flowering age, panicle length, and grain amount. Harvest age means the faster the plant enters the generative phase earlier.

\section{Number of productive tillers}

The highest number of productive tillers is the Siganteng genotype with an average of 13 while the lowest average number of productive tillers is found in the Sigudang 4 genotype (Table 2). According to [13]. productive tillers can be grouped into three types, namely less tillers (less than 12 stems per clump), medium tillers (13-20 stems per clump) and many tillers (more than 20 stems per clump).

\section{Rice Per Rice Panai}

Quantitative observations on the number of grains with permalent contents were 118 genotypes and a few were coal genotypes 41 (Table 4). The number of filled grain per panicle will determine the productivity of the plant if the panicles formed produce a lot of rice that is pithy, then the productivity of rice plants is high[10]. The amount of grain is determined by the number of productive tillers and the age of flowering earlier, where pollination will succeed and produce a lot of rice. Cooking or the process of filling rice with starch in plants derived from photosynthetic sources and from assimilation sources before flowering which is stored in stem and leaf tissues is then converted into sugar and transported to the fruit.

\section{Hollow Grain Percentage Per Panai}

Quantitative observations on the number of percentage of empty grain per panicle are coal genotypes 72.4 and fewer, namely Zahra genotype 59.06 (Table 4). The higher quality of rice plants is influenced by the number of filled grain and at least empty grain. Many farmers want at least grain vacuum contained in the crop because it can reduce the weight of the paddy harvest. The components that affect the empty grain are dry weight, total grain content and 1000 grain weight [2], [5] and [10]. 
The small amount of empty grain will affect the size of plant productivity. If in a panicle there is a grain which is mostly empty so that it will affect the productivity of plants which are getting lower and the weight per hectare is getting smaller. Factors that cause a lot of grain, namely splash, lack of light intensity and dry leaves, this causes starch in rice grains to shrink and disturbed.

\section{Amount of Unbalanced Total Grain}

The most quantitative observations of the total number of seed grains found were the sad genotype 134.2 and the least found in the bujingwangi genotype 55.6 (Table 2). The difference from the total number of grain per panicle is thought to be caused by the genetic influence of different cultivars. But apart from genetic influences, environmental factors also affect the total grain count per panicle. [4], [7] and [9] states that the properties of each genetic and environmental growth of varieties will affect the grain density of each panicle. Voidness can also be caused by non-genetic factors, such as pests and diseases. 8. Grain Weight Total Per Clump (g)

Quantitative observations on total grain weight per clump were found in the sigudang genotype of $86.2 \mathrm{gr}$ and the least found in the zahra genotype was $41.4 \mathrm{gr}$ (Table 3). There is a difference in total grain weight of clumps influenced by genetic factors. This is consistent with the statement of [1], [3] and [8] that the difference in total production can be caused by differences in the genetic composition of each rice cultivar, so that the response to the environment is also different. Besides genetics, environmental factors also influence plant production.

Table.1: Average Quantitative Character of Local Rice Plants Based on Plant Height, Flowering Age, Harvest

\begin{tabular}{|c|c|c|c|c|}
\hline Genotype & Plant Height $(\mathrm{cm})$ & Fowering Age (hst) & $\begin{array}{l}\text { Harvest } \\
\text { Age(hst) }\end{array}$ & $\begin{array}{c}\text { Harvest Age Total } \\
\text { Tiller Number }\end{array}$ \\
\hline Mirah & 99 & 105 & 142 & 10 \\
\hline Batubara & 101 & 105 & 140 & 13 \\
\hline Tebing & 95 & 98 & 128 & 11 \\
\hline Sigudang & 103 & 120 & 152 & 14 \\
\hline Sisorang & 87 & 95 & 125 & 9 \\
\hline Siganteng & 177 & 150 & 180 & 20 \\
\hline Zahra & 126 & 110 & 140 & 16 \\
\hline Bujing Wangi & 135 & 120 & 150 & 18 \\
\hline
\end{tabular}

Table.2: Genotype Number of Productive and Puppies Amount of Total Grain Per Panai

\begin{tabular}{lll} 
Genotype & Number of Productive & Pupppies Amount of Total per Panai \\
\hline Mirah & 10 & 134,2 \\
Batubara & 8 & 88,8 \\
Tebing & 12 & 92,2 \\
Sigudang & 4 & 99,6 \\
Sisorang & 6 & 106,2 \\
Siganteng & 13 & 96,6 \\
Zahra & 11 & 112,6 \\
Bujing Wangi & 9 & 55,6 \\
\hline
\end{tabular}

Table.3: Grain Weight Total per Clump $(\mathrm{g})$

\begin{tabular}{ll}
\hline Genotipe & Grain Weight Total per Clump (g) \\
\hline Mirah & 45 \\
Batubara & 44,2 \\
Tebing & 45,2 \\
Sigudang & 86,2 \\
Sisorang & 43,6 \\
Siganteng & 44,6 \\
Zahra & 41,4 \\
Bujing Wangi & 44,4 \\
\hline
\end{tabular}




\section{CONCLUSION}

Sigudang genotype was the best genotype with a total grain weight of 82.6 grams. Genotype Sis orang have a good agronomic appearance.

\section{ACKNOWLEDGMENT}

I want to say many thanks to head the Study Program of Agrotechnology Faculty Of Agriculture Muhammad University South Tapanuli North Sumatera. Thanks to Department of Agronomy postgraduate Andalas University.

\section{REFERENCES}

[1] Abdullah, B. 2009. Progress of Rice Through Recurrent Selection. J.Agron. zIndonesian. 37 (3):188-193

[2] Agung W.S, Supriyanti dan Kristanini. 2017. Keragaman sepuluh kultivar padi lokal (Oryza sativa L.) Daerah Istimewa Yokjakara. 2017. Jurnal. Vegetlika. 6(4): 55-70

[3] Alfons. 2011. Varetas Unggul Padi Untuk Bahan Pangan dan Industri

[4] Jumin, H. B. 2002. Agroekologi : Suatu Pendekatan Fisiologis.

[5] Sajid. M, S.A. Khan, H. khurshid, J. Iqbal, A. Muhammad, N. Saleen, S.M.Ali Shah.2015. Characterization of Rice (Oryza sativa L.) Germplasm Through Various Agro-Morphological Traits. J.Scientia Agriculture. ((2) :83-88.

[6] Sajah. A. 2012. Karakteristik Morfologi malai plasma nutfah padi lokal asal kabupaten Tana Toraja Utara. Sulawesi Selatan. Universitas Hasanuddin. Sulawesi Selatan.

[7] Sajah. A. 2012. Karakteristik Morfologi malai plasma nutfah padi lokal asal kabupaten Tana Toraja Utara. Sulawesi Selatan. Universitas Hasanuddin. Sulawesi Selatan.

[8] Senewe, R.E. dan J.B. Alfons. 2011. Kajian adaptasi beberapa varietas unggul baru padi sawah pada sentrapadi di Seram Bagian barat Provinsi Maluku. Jurnal Budidaya Pertanian. 7(1): 60-64

[9] Sitaresmi. T. Rina. H, Wening, Amir.T. Rakhmi, N. Yunani dan U, Susanto. 2013. Pemanfaatan plasma nutfah padi varietas lokal dalam perakitan varietas unggul. Iptek Tanaman Pangan. Vol. 8 No.1. hal 2230.

[10] Siregar, Hadrian. 1981. Budidaya Tanaman Padi Di Indonesia. Sastra Hudaya. Bogor.

[11] Sunarsedyono, 2001. Budidaya Padi Sawah Secara Ratun. Teknologi Untuk Menjelang Peningkatan Produksi Tanaman Pangan. Badan Litbang Pertanian. Pus litbangtan. Balitkabi. P: 32-41
[12] Syukur. M, S.Sriani dan Y.Rahmi. 2012. Teknik Pemuliaan Tanaman. Penebar Swadaya. Jakarta. 71 hal.

[13] Zen, K.,R. Setiamihardja, Murdaningsih, T. Suganda. 2002. Aktivitas Enzim Peroksidase Pada Lima Genotip Padi. Zuriat 13 (2): 97-105. 